\title{
The original non-volant land mammal fauna of Faure Island, Shark Bay, Western Australia
}

\author{
Alexander Baynes \\ Department of Earth and Planetary Sciences, Western Australian Museum, \\ Locked Bag 49, Welshpool DC, WA 6986 Australia; E-mail: alex.baynes@museum.wa.gov.au
}

\begin{abstract}
Remains of four species of non-volant native mammals have been found on Faure Island: Perameles bougainville (Western Barred Bandicoot), Bettongia penicillata (Woylie or Brush-tailed Bettong), Pseudomys fieldi (Shark Bay Mouse) and Rattus tunneyi (Pale Field-rat). Three of these species, Pe. bougainville, B. penicillata and PS. fieldi, are abundant and their remains are recorded from several or most dune 'blowout' sites and all are recorded from a substantial cave deposit. These three were members of the original (i.e. immediately pre-European) fauna of Faure Island. Rattus tunneyi, in contrast, is known from a single specimen from a dune blowout, but is not recorded from the cave deposit. It appears unlikely to have been a member of the original fauna, but rather the specimen may be a relict from an earlier fauna, or may have been carried to the island from the mainland by a predator. Comparison with other islands in Shark Bay suggests that, at some 5800 ha in area, Faure Island should have carried more than three mammal species. There is no evidence that the island has been significantly smaller at any time since it was formed by rising sea level about 7000 years ago. A lack of habitat diversity or extremes of temperature or drought may have reduced the number of mammal species over the millenia, or it is just possible that the original fauna may have included other small species with restricted habitat requirements whose remains have not been detected. It is, however, very unlikely that any other medium-sized mammal originally occurred on the Island.
\end{abstract}

Key words: relict, cave deposit, island, Shark Bay

\section{INTRODUCTION}

Faure Island is one of many continental shelf islands along the Western Australian coast cut off from the mainland by glacio-eustatic sea level rise in the most recent glacial-interglacial cycle (Main 1961; Wilson 2008). Geomorphologically, it is part of the eastern prong of Peron Peninsula, which is a ridge that lies above present sea level probably because it is underlain by an anticline (Hocking et al. 1987; Playford 1990). The Peninsula and Faure Island are composed mainly of Peron Sandstone, overlain by red aeolian Nilemah Sands (Hocking et al. 1987; Playford 1990). Minor marine units and 'white' Holocene aeolian dunes occur around the coasts. The latter, are particularly prevalent in areas of coast where the southerly summer sea 'breezes' blow onshore.

Although there are no data bearing directly on the question of the exact timing of the separation of Faure Island from Peron Peninsula, this is likely to have occurred about 7000 calendar years ago, when present sea level was first reached (Thom and Chappell 1975: radiocarbon dates recalibrated). The water gap between Petit Point (on Peron Peninsula) and Faure Island is very shallow
- there is anecdotal evidence that under suitable conditions of water depth, which is mainly controlled by tidal and seasonal effects, emus can wade across it (R.E. Johnstone personal communication March 2000; J.N.S. Williams personal communication October 2006), and it is shown on some maps as all tidal flats. But there has been uplift of the land of about $2 \mathrm{~m}$ compared to mean sea level in Shark Bay during the Holocene (Thom and Chappell 1975), presumably decreasing the water depth since 7000 years ago. The Faure Sill, that runs from the east of Faure Island to the mainland, formed about 4200 years ago (Playford 1990), subsequent to island formation and sea level stabilization, and is a new structure rather than the remains of the last land connection to the Island. Therefore the last connection was to Peron Peninsula, and the mammal fauna on the diminishing land mass that would become Faure Island would have been a subset of that then occurring on Peron Peninsula, which would itself have been a subset of the regional fauna, due to the peninsula effect. The original (i.e., immediately pre-European) land mammal fauna of Peron Peninsula has been 
investigated by Baynes (1990, 2000, 2007) using remains from the surfaces of small cave deposits.

No specimens of living native non-volant mammals are known to have been obtained from Faure Island, and nothing was known about its original mammal fauna until 1972, when the skull of a Woylie (or Brush-tailed Bettong, Bettongia penicillata), picked up on the island by Dick Hoult, was donated to the Western Australian Museum. That specimen was placed in the modern mammal collection, with the catalogue number M9544. Greg Harold and Angela Sanders visited Faure Island in November 1989 in the course of a survey of the Shark Bay region undertaken as a contract for the then Department of Conservation and Land Management (G.R. Harold personal communication April 2000). They set out several trap lines and ran them for several nights, and caught House Mice (Mus musculus) but no native mammals. During a visit to the Island by Martin Copley and Tim Flannery in December 1999 further skeletal material was obtained from dune blowouts on the west coast, near where the original skull had been found. The bones included more jaw specimens of Woylie, three jaws of Shark Bay Mouse (Pseudomys fieldi) and three damaged limb bones consistent with Western Barred Bandicoot (Perameles bougainville). In April 2000 Martin Copley and Barry Wilson found more Woylie remains in a dune blowout at the southwestern corner of the Island.

\section{MATERIALS AND METHODS}

I joined the Faure Island biological survey expedition for one week, 23-29 May 2000, to search for further mammal skeletal remains, and try to discover the full original non-volant mammal fauna. Reports from Martin Copley, and results obtained on earlier visits by others (above), suggested that such remains might be found in two types of situations: the dune blowouts and in small caves in the cliffs along some parts of the Island coast. I therefore concentrated on such areas, searching caves in cliffs along the southern east coast and northern west coast, and sand dune blowouts along the south and west coasts. I did not visit the north coast, the northern east coast, or the spit on the southern side of the main mangrove. In July 2006 Jiri and Marie Lochman discovered an owl pellet deposit in a small cave in a cliff at the northern end of the east coast of the Island. I visited the Island again 20-22 October 2006, and located two caves in that area that contained native mammal bones. I made a large collection from one of them, which subsequent discussion with Jiri Lochman has confirmed was the cave that he found (J. Lochman personal communication July 2007).

The bone material obtained during both periods of field work was identified, using, where necessary, comparative material from the vertebrate palaeontological collection of the Western Australian Museum.

\section{RESULTS}

\section{Sites}

I failed to find a single bone of a native mammal in any of the caves during the 2000 field work. I found that surprising, as such remains can usually be found in coastal caves around most of Shark Bay and its other islands (Baynes 1990, 2000). It is not clear why the only owl pellet deposit should occur in the cliff at the northern end of the east coast, when many of the caves in the other cliffed areas appear to be suitable as owl roosts. There may be a subtle difference in the geology of the rock in which the caves have developed, perhaps being slightly more alkaline, contributing to the preservation of bone; or the explanation may lie in the former presence on the Island of goats which had used the larger caves as shelters, kicking the contents out onto the talus slopes below, where bones rapidly deteriorate in the sun, as is still happening on Dirk Hartog Island (Baynes 2006). The Faure Island dune blowouts, on the other hand, were almost all productive in 2000.

The sites (Figure 1) are described below and are numbered around the island in a clockwise direction beginning with the large blowout behind the main mangrove at the southern end of the west coast.

B1. Big blowout in 'white' dunes stretching for about $1 \mathrm{~km}$ along the curved north-east coast of the main mangrove. Centre of site GPS

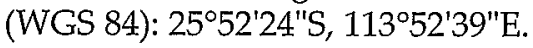

B2. Blowout in 'white' dunes on the northern coast of the next bay to the north-west of $\mathrm{B} 1$; dunes not so high or extending so far inland as B1. No GPS co-ordinates recorded.

B3. Blowout in a high red dune at the western end of the main east-west fence. This is where the original Woylie specimen was found (D. Hoult personal communication May 2000). No GPS co-ordinates recorded.

B4. Blowout in a 'white' dune at the western end of the main east-west fence, just to the north of B3. No GPS co-ordinates recorded.

B5. Big blowout in a large red dune on the northern west coast of the island. Centre of site GPS (standard not recorded): $25^{\circ} 49^{\prime} 49^{\prime \prime}$ S., $113^{\circ} 51^{\prime} 14^{\prime \prime} \mathrm{E}$.

B6. Blowout in small pinkish 'white' dune, near the old pearlers' camp on the north-west point of the Island. GPS (standard not recorded): $25^{\circ} 49^{\prime} 01^{\prime \prime} \mathrm{S}, 113^{\circ} 51^{\prime} 13^{\prime \prime} \mathrm{E}$.

C1. Small cave in low cliff about $5 \mathrm{~m}$ above sea level at the northern end of the east coast, found by A. Baynes, J.N.S. Williams and C.C. 


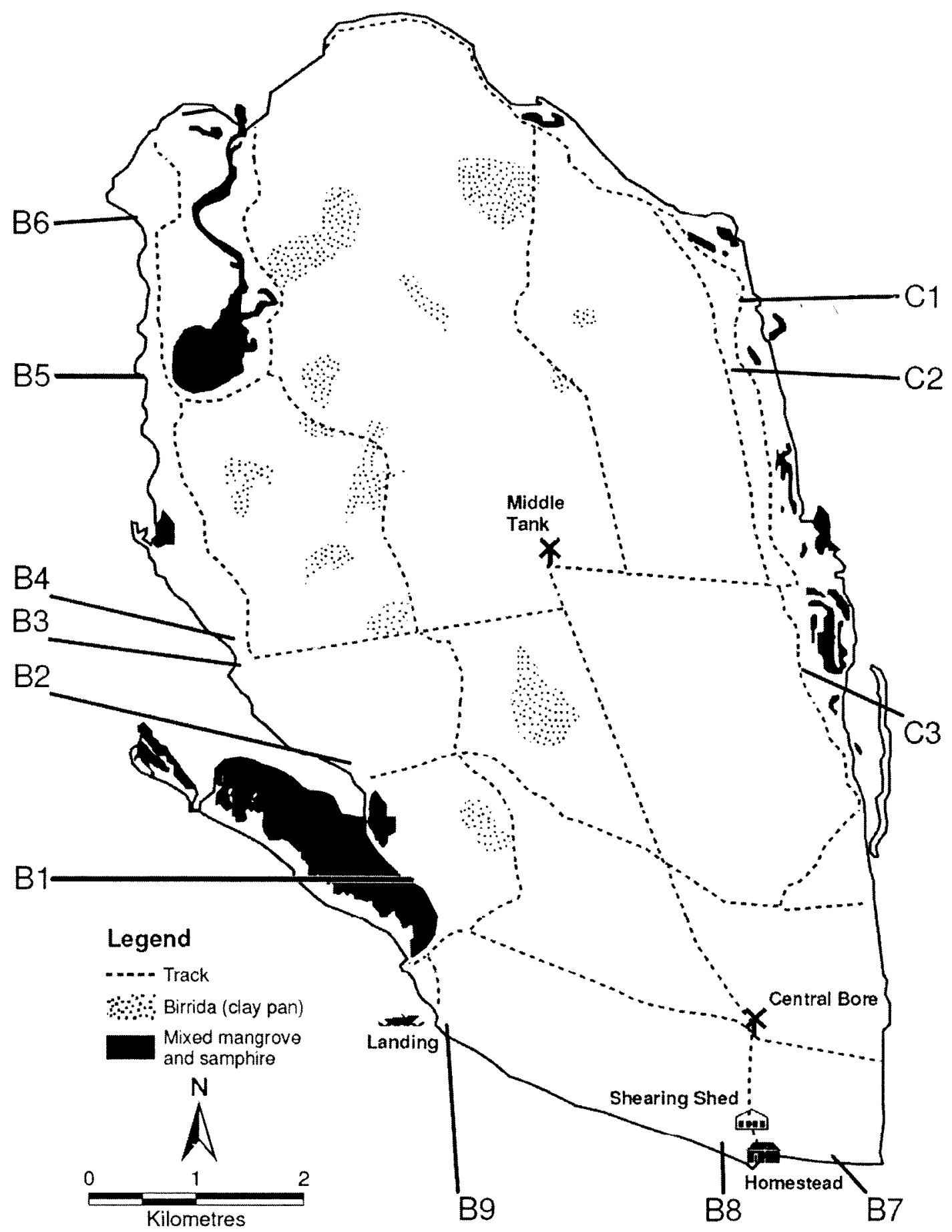

Figure 1 Location of mammal bones collected on Faure Island including Sites C1 to C3 and B1 to B9.

Stephens, 21 Oct 2006. GPS (WGS 84): $25^{\circ} 49^{\prime} 30^{\prime \prime} \mathrm{S}, 113^{\circ} 54^{\prime} 34^{\prime \prime} \mathrm{E}$.

C2. Small cave at the southern end of the most northerly sweep of cliff on the east coast of the Island. First discovered by J. and M. Lochman, 19 lul 2006, who collected bones from it Relocated by A. Baynes, 21 Oct 2006. GPS (WGS 84): 254951'S, $1135431^{\prime \prime} \mathrm{E}, 7 \mathrm{~m}$ a.s.l. Sediments dug out of the cave to a depth of about $5 \mathrm{~cm}$ and screened on $22 \mathrm{Oct} 2006$ by $\mathrm{A}$. Baynes and C.C. Stephens.

C3. Cliff on the mid east coast adjacent to a spit with mangroves. No GPS co-ordinates recorded.

B7. Blowout in 'white' dunes along the south coast east of the homestead. No GPS co-ordinates recorded.

B8. Blowout in 'white' dunes along the south coast west of the homestead. No GPS co-ordinates recorded

B9. Blowout in pinkish-coloured dune just east of the landing cove. No GPS co-ordinates recorded." 


\section{Mammal species}

The numbers of identified mammal remains recorded from the various sites, including those collected by others, are given in Table 1 . In most cases the numbers are based upon tooth rows from left and right upper and lower jaws. But counts of Perameles from site C2 are based upon calcanea (heel bones: one right, one left per animal), which are much more abundant in that sample than jaws. Practically all the remains are dissociated, so in the very few cases where left and right upper tooth rows are associated these are counted as two jaws. However, the skull and two lower jaws from site B7 are almost certainly from the same animal, so these are counted as one individual, differentiated from the other counts by placing the number in brackets.

\section{Tachyglossus aculeatus (Short-beaked Echidna)}

The echidna was almost certainly not a member of the original fauna of the Island, because none of its highly characteristic skeletal remains have been found in any of the blowout sites. The Hoult family reported in 2000 that one echidna (or "porcupine") was seen on the Island in the 1930s and 1940s, and that they had introduced another one within the previous decade. No actual sightings of echidna were made during the survey. But, in addition to the signs found in the east coast cliffs by members of the survey expedition, echidna tracks no more than a week old were shown to me by Dick Hoult in 'white' dunes near the well to the south-west of the homestead. It seems unlikely that both animals still survived on the island, and more probable that one animal was moving between the two areas. Cliffs with caves are favourite shelters for echidnas, and the C 3 area appeared to have been used a relatively short time before the survey as the scat was fairly fresh (still smelly).

\section{Perameles bougainville (Western Barred Bandicoot)}

Remains of this species from three different blowout sites in 'white' dunes and one cave deposit in the cliffs at the northern end of the east coast, establish that this species was a member of the original mammal fauna of the Island.

Bettongia penicillata (Woylie or Brush-tailed Bettong)

Remains of the Woylie are abundant and recorded from all of the Island sites that contained bone, probably because its jaws are large and resistant to weathering, and obvious on the ground to a searcher. The species was clearly a member of the original fauna. It would be desirable to use all the Faure Island material, and that from the sites on Peron Peninsula, to check that these populations were conspecific with true $B$. penicillata of southwestern Australia, rather than the poorlyknown arid zone brush-tailed bettong Bettongia anhydra Finlayson, 1957, originally described as a subspecies of $B$. penicillata.

\section{Pseudomys fieldi (Shark Bay Mouse)}

Remains of this species from three different blowout sites in 'white' dunes, B1, B2 and B4, and abundant remains from cave $\mathrm{C} 2$, establish that this species was also a member of the original mammal fauna of the Island.

\section{Rattus tunneyi (Pale Field-rat)}

This species is only represented by a single jaw from the B1 'white' dune blowout. Where it occurs on the mainland in the Shark Bay area $R$. tunneyi is typically abundant in both cave deposits and as a living animal in Holocene 'white' coastal dunes. It is possible that the single specimen dates from a time when Faure Island was part of Peron Peninsula (where the species was part of the original fauna: Baynes 1990, 2000, 2007). However, the specimen is white in colour and therefore probably originates from within a 'white' dune, which, since the blowouts contain abundant marine mollusc shells, probably post-dates sea

Table 1 Numbers of bone remains of non-volant terrestrial mammal species recorded from various sites on Faure Island. $-=$ not recorded; $(1)=$ one individual $(4$ jaws); $X=$ record based on non-skeletal material (spine and scat).

\begin{tabular}{|c|c|c|c|c|c|c|c|c|c|c|c|c|}
\hline & $\begin{array}{l}\mathbf{B} \\
1\end{array}$ & $\begin{array}{l}\text { B } \\
2\end{array}$ & $\begin{array}{l}\text { B } \\
3\end{array}$ & $\begin{array}{l}\text { B } \\
4\end{array}$ & $\begin{array}{l}\mathbf{B} \\
\mathbf{5}\end{array}$ & $\begin{array}{l}\text { B } \\
6\end{array}$ & $\begin{array}{l}\mathrm{C} \\
1\end{array}$ & $\begin{array}{l}\mathrm{C} \\
2\end{array}$ & $\begin{array}{l}C \\
3\end{array}$ & $\begin{array}{l}\text { B } \\
7\end{array}$ & $\begin{array}{l}\text { B } \\
8\end{array}$ & $\begin{array}{l}\text { B } \\
9\end{array}$ \\
\hline Tachyglossus aculeatus & & & & & & & & & & & & \\
\hline (Short-beaked Echidna) & - & - & - & - & - & - & - & - & $x$ & - & - & - \\
\hline Perameles bougainville & & & & & & & & & & & & \\
\hline $\begin{array}{l}\text { (Western Barred Bandicoot) } \\
\text { Bettongia penicillata }\end{array}$ & 4 & 2 & - & 3 & - & - & - & 16 & - & - & - & - \\
\hline (Woylie) & 128 & 14 & 1 & 3 & 4 & 2 & 2 & 1 & - & (1) & 6 & 1 \\
\hline $\begin{array}{l}\text { Pseudomys fieldi } \\
\text { (Shark Bay Mouse) }\end{array}$ & 2 & 5 & - & 3 & - & - & - & 197 & - & - & - & - \\
\hline $\begin{array}{l}\text { Rattus tunneyi } \\
\quad \text { (Pale Field-rat) }\end{array}$ & 1 & - & - & - & - & - & - & - & - & - & - & - \\
\hline $\begin{array}{l}\text { Mus musculus } \\
\text { (House Mouse) }\end{array}$ & - & - & - & - & - & - & - & - & - & - & - & - \\
\hline
\end{tabular}


level reaching its present height, and island formation, about 7,000 years ago.

\section{Mus musculus (House Mouse)}

A small brown mouse, identified by G.R. Harold in 1989 as Mus musculus, is common on Faure Island, and was trapped during the biological survey in 2000 (Schmitz and Richards 2008). Interestingly, no remains of $M$. musculus were found in the cave deposits, or picked up from any of the blowout sites, in spite of their abundance in the surrounding Spinifex yegetation, as indicated by the frequency of small murid tracks on the dunes. This may indicate that there were sufficient scavengers, in the form of Gould's Monitor (Varanus gouldii), birds of prey and/or feral Cats, on the Island to consume any animals that died. On other islands in the region with native mammal faunas (such as Bernier), skeletal remains are quite common on the surface of the ground (author's unpublished observations). Also, Shortridge (1936) picked up the skull of a Shark Bay Mouse (reported under the name "Mus gouldi") on Bernier Island in 1906.

\section{DISCUSSION}

\section{The age of the mammal remains from cave $\mathrm{C} 2$}

Although the owl pellet deposit in cave C2 was not discovered until 2006, that is, after the reintroduction to Faure of Pseudomys fieldi in 2002 and Perameles bougainville in 2005, it almost certainly contains the original fauna of the Island, and not remains of the recently re-introduced populations. The most important evidence for this 'is the complete absence of Mus musculus from the sample. If the desposit had been accumulated within the last decade, it is extremely improbable that there would be so many remains of $P$. fieldi and not a single specimen of Mus. Also, no intact owl pellets remained in the $\mathrm{C} 2$ deposit, and the mammal bones vary in colour from cream to light brown, consistent with having lain in the deposit for decades or even centuries. None of the mammal material has the typical translucent silver-white çolour of very recently accumulated bones.

\section{The original non-volant native mammal fauna of Faure Island}

The original non-volant native mammal fauna of Faure Island is compared with that recorded from the eastern side of Peron Peninsula in Table 2. As expected, the original fauna of Faure Island is a small subset of that of Peron Peninsula.

The fact that remains of Rattus tunneyi are not recorded in the large C2 sample indicates that it was almost certainly not a member of the Island fauna of two centuries ago. On Peron Peninsula remains of $R$. tunneyi are found in most deposits in coastal sites, adjacent to a large range of local habitat types (Baynes 2000, 2007). If the species had been on the Island its remains would have been included in C2. The single specimen from the B1 blowout may represent a population that persisted on the Island for some time after its formation but finally died out centuries or even millenia ago, or it may have been transported to the island from the mainland in the stomach of a, presumably avian, predator. Absence of $R$. tunneyi from Faure Island is consistent with its absence from all other Shark

Table 2 The original non-volant mammal faunas of eastern Peron Peninsula (PP) (data from Baynes 1990, 2007; McKenzie et al. 2000) and Faure Island (FI). X = recorded; $-=$ not recorded.

\begin{tabular}{lll}
\hline Species & PP & FI \\
\hline Tachyglossus aculeatus (Short-beaked Echidna) & $\mathrm{X}$ & - \\
Dasycercus sp. (Mulgara or possibly Ampurta) & $\mathrm{X}$ & - \\
Dasyurus geoffroii (Chuditch / Western Quoll) & $\mathrm{X}$ & - \\
Phascogale calura (Red-tailed Phascogale) & $\mathrm{X}$ & - \\
Sminthopsis crassicaudata (Fat-tailed Dunnart) & $\mathrm{X}$ & - \\
Sminthopsis dolichura (Little long-tailed Dunnart) & $\mathrm{X}$ & - \\
Sminthopsis hirtipes (Hairy-footed Dunnart) & $\mathrm{X}$ & - \\
Isoodon obesulus (Quenda/Southern Brown Bandicoot) & $\mathrm{X}$ & - \\
Perameles bougainville (Western Barred Bandicoot) & $\mathrm{X}$ & $\mathrm{X}$ \\
Bettongia penicillata (Woylie / Brush-tailed Bettong) & $\mathrm{X}$ & $\mathrm{X}$ \\
Lagorchestes hirsutus (Rufous Hare-wallaby) & $\mathrm{X}$ & - \\
Lagostrophus fasciatus (Banded Hare-wallaby) & $\mathrm{X}$ & - \\
Macropus robustus (Euro) & $\mathrm{X}$ & - \\
Onychogalea lunata (Crescent Nailtail Wallaby) & $\mathrm{X}$ & - \\
Leporillus apicalis (Lesser Stick-nest Rat) & $\mathrm{X}$ & - \\
Leporillus conditor (Greater Stick-nest Rat) & $\mathrm{X}$ & - \\
Notomys alexis (Spinifex Hopping-mouse) & $\mathrm{X}$ & - \\
Pseudomys fieldi (Shark Bay Mouse) & $\mathrm{X}$ & $\mathrm{X}$ \\
Pseudomys hermannsburgensis (Sandy Inland Mouse) & $\mathrm{X}$ & - \\
Rattus tunneyi (Pale Field-rat) & $\mathrm{X}$ & - \\
\hline
\end{tabular}


Bay islands (Baynes 1990), even though it was widespread on the peninsulas and adjacent mainland. Although $R$. tunneyi is recorded from islands in northern Australia, including two in the Bonaparte Archipelago off northwest Kimberley (McKenzie et al. 1978), and six islands in the Dampier Archipelago, it does not seem to have been able to survive in the long term on more southerly and westerly islands, being also absent from Barrow Island.

\section{Species-area considerations}

The theory of island biogeography, and the species-area relationship are well established (e.g., MacArthur and Wilson 1967; May 1975; Lawlor 1986), although still undergoing some fine-tuning (e.g. Williamson et al. 2001). The species-area relationships of native mammals on the continental shelf islands along the western and southern coasts of Australia were investigated by Kitchener et al. (1980), though they did not include Faure Island in their analysis, presumably because only the Woylie was known from the island at that time. Table 3 shows the areas and numbers of non-volant native mammal species recorded from the four large islands in Shark Bay. The mammal data are drawn from Baynes (1990, 2000, 2006), and this study, rather than Kitchener et al. (1980), because they omitted one species from Bernier Island (Pseudomys desertor), for a total of six rather than seven species, and the original fauna of Faure was unknown in 1980. The table shows that Faure Island is slightly larger than Bernier or Dorre, but has fewer native mammals recorded from it than either. Kitchener et al. (1980: figure 10) plotted estimated numbers of mammal species in the "pristine" (i.e. original in my terminology) faunas against area (both variables transformed as logarithms to the base 10). Using their regression line to estimate the likely number of species for an island of 5800 ha indicates that Faure would be expected to carry at least seven species rather than three. There appear

Table 3 Areas in hectares (Ha) and original numbers of non-volant native mammal species (Mam. spp.) recorded from the four large islands in Shark Bay. Area data from Kitchener et al. (1980) and this study; mammal data from Baynes (1990, 2000, 2006) and results of this study.

\begin{tabular}{lll}
\hline Island & Ha & Mam. spp. \\
\hline Dirk Hartog & 59600 & 13 \\
Faure & 5800 & 3 \\
Bernier & 4640 & 7 \\
Dorre & 4420 & 5 \\
\hline
\end{tabular}

to be four possible explanations for this discrepancy:

1) The area of the island was at some stage substantially smaller than at present, and has increased significantly to its current area as a result of the Holocene uplift noted by Thom and Chappell (1975).

2) The original mammal fauna of the Island included more than three species, but no remains of the others have been discovered.

3) Three was the original number of mammal species because the relative homogeneity of habitats on Faure allowed the survival of no more than that number.

4) Lying in the eastern side of Shark Bay, Faure Island has a less maritime and equable climate than the other three, in particular experiencing higher summer maximum temperature extremes and less rainfall, especially reliable winter rainfall. Extremes of drought and/or temperature may have led to the extinction of mammal species that persisted for a time after island formation.

The first possibility, substantially smaller island area since 7000 years ago, can probably be ruled out. Although there are minor areas of progradation in the mangrove developments at the southwest corner of the Island, on the northern coast and along much of the east coast, most of the Island forms a plateau that is at least $5 \mathrm{~m}$ above present sea level, and would have remained above sea level since the Last Interglacial. Because the remains of Woylie were so abundant, it seems extremely unlikely that the original fauna of Faure Island included any other medium-sized mammal whose remains were not found. The fact that the very large C2 sample contains the same three species whose remains are found throughout the Island, and no others, suggests that there were no other small or mediumsized mammal species on the Island either. However, the single specimen of Rattus tunneyi shows that that possibility cannot be completely ruled out. Beard (1976) mapped the vegetation on Faure Island as Acacia scrub, Acacia thicket and samphire, less diverse than the habitats on Bernier and Dorre Islands. The 'white' dune habitats with grasses and Acanthocarpus thickets would not have been present when Faure Island first formed, but have been built by aeolian movement of sand and shell fragments from the beaches over the millenia. The possibility of the elimination of species from Faure Island by extreme climatic events is also difficult to assess, particularly in the absence of any meteorological data. The Woylie, however, assuming that it is correctly identified, is an aboveground nesting (as opposed to burrowing) southwestern species, close to its northern distributional range limit. These characteristics would seem to make it vulnerable to climatic 
extremes of heat or drought, but it apparently survived on the Island until the time of European colonization.

Overall, it seems most likely that the original nonvolant mammal fauna of Faure Island consisted of the three species detected during recent investigations, but one or two additional small species occurring in restricted habitats cannot be completely ruled out.

\section{ACKNOWLEDGEMENTS}

I am grateful to Martin Copley for inviting me to take part in the May 2000 biological survey expedition to Faure Island, and providing me with a contract to carry out the work. It was a privilege to join such a large and interesting group of people, and the inclusion of an excellent cook in the crew made it a rare treat. Australian Wildlife Conservancy flew me to Faure Island in October 2006, and Jo Williams looked after me when I got there. I thank her, Craig Stephens and Steffi Hilmer for assistance with field work. Jeff Short made constructive comments on a draft of the paper.

\section{REFERENCES}

Baynes, A. (1990). The mammals of Shark Bay, Western Australia (pp. 313-325). In: Berry, P.F., Bradshaw, S.D. and Wilson, B.R. (eds), Research in Shark Bay. Report of the France-Australe Bicentenary Expedition Committee. Western Australian Museum Press, Perth, WA.

Baynes, A. (2000). Original mammal faunas of the Carnarvon Basin, based on fossil material from the surfaces of small caves. Appendix 2 In: McKenzie, N.L., Hall, N.J. and Muir, W.P. Non-volant mammals of the southern Carnarvon Basin, Western Australia. Records of the Western Australian Museum Supplement 61: 479-510.

Baynes, A. (2006). The original mammal fauna of Dirk Hartog Island: results from field work in 2006. Unpublished report to the Department of Environment and Conservation. 6 pp.

Baynes, A. (2007). Final report on an investigation of the original non-volant mammal fauna of Nanga Station, Shark Bay. Unpublished report to the Department of Environment and Conservation. 9 pp.

Beard, J.S. (1976). Vegetation survey of Western Australia: The Vegetation of the Shark Bay and Edel Area, Western Australia. Map and Explanatory Notes. 1:250,000 series. Vegmap Publications, Perth, WA.

Finlayson, H.H. (1957). Preliminary description of two new forms of Bettongia (Marsupialia). The Annals and Magazine of Natural History (12) 10: 552-554.
Hocking, R.M., Moors, H.T. and van de Graaff, W.J.E. (1987). Geology of the Carnarvon Basin, Western Australia. Geological Survey of Western Australia Bulletin No. 133: i-xiv, 1-289.

Kitchener, D.J., Chapman, A., Muir, B.G. and Palmer M. (1980). The conservation value for mammals of reserves in the Western Australian wheatbelt. Biological Conservation 18: 179-207.

Lawlor, T.E. (1986). Comparative biogeography of mammals on islands. Biological Journal of the Linnean Society 28: 99-125.

MaçArthur, 'ं.H' and Wilson, E.O. (1967). The theory of island biogeography. Princeton, Princeton University Press, i-xi, 1-203.

Main, A.R. (1961). The occurrence of Macropodidae on islands and its climatic and ecological significance. Journal of the Royal Society of Western Australia 44: 84-89.

May, R.M. (1975). Patterns of species abundance and diversity (pp. 81-120). In: Cody, M.L. and Diamond, J.M. (eds), Ecology and evolution of communities. Belknap Press, Cambridge, Massachusetts, U.S.A.

McKenzie, N.L., Burbidge, A.A., Chapman, A. and Youngson, W.K. (1978). Part III. Mammals (pp. 2228). In: Burbidge, A.A. and McKenzie, N.L. (eds), The islands of the north-west Kimberley, Western Australia. Wildlife Research Bulletin, Western Australia No. 7.

McKenzie, N.L., Hall, N.J. and Muir, W.P. (2000). Nonvolant mammals of the southern Carnarvon Basin, Western Australia. Records of the Western Australian Museum Supplement 61: 479-510.

Playford, P.E. (1990). Geology of the Shark Bay area, Western Australia (pp. 13-31). In: Berry, P.F., Bradshaw, S.D. and Wilson, B.R. (eds), Research in Shark Bay. Report of the France-Australe Bicentenary Expedition Committee. Western Australian Museum Press, Perth, WA.

Schmitz, A. and Richards, J.D. (2008). A survey of the terrestrial vertebrates of Faure Island, Shark Bay, Western Australia. Records of the Western Australian Museum Supplement 75: 33-37.

Shortridge, G.C. (1936). Field notes (hitherto unpublished) on Western Australian mammals south of the tropic of Capricorn (exclusive of Marsupialia and Monotremata), and records of specimens collected during the Balston Expeditions (November 1904 to June 1907). Proceedings of the Zoological Society of London 1936: 743-749.

Thom, B.G. and Chappell, J.M.A. (1975). Holocene sea levels relative to Australia. Search 6: 90-93.

Williamson, M., Gaston, K.J. and Lonsdale, W.M. (2001). The species-area relationship does not have an asymptote! Journal of Biogeography 28: 827-830.

Wilson, B. (2008). Background information on Faure Island, Shark Bay, Western Australia. Records of the Western Australian Museum Supplement 75: 1-9. 